
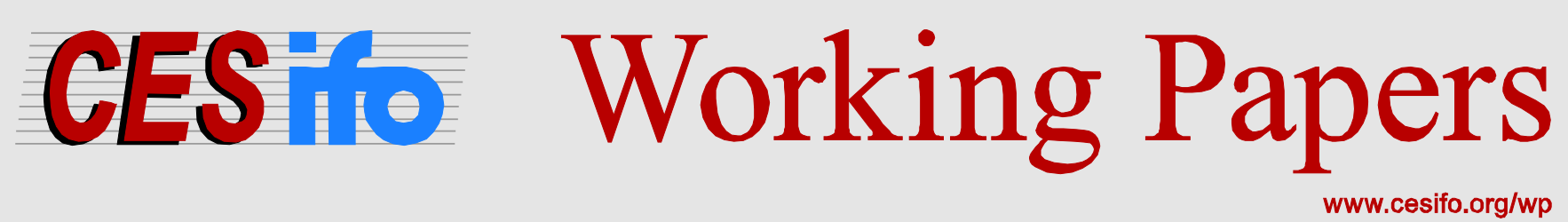

\title{
CCS - Failing to Pass Decision Gates
}

\author{
Magne Emhjellen \\ Petter Osmundsen
}

\author{
CESIFO WORKING PAPER NO. 4525 \\ CATEGORY 9: RESOURCE AND ENVIRONMENT ECONOMICS \\ DECEMBER 2013
}

An electronic version of the paper may be downloaded

- from the SSRN website:

- from the RePEc website:

- from the CESifo website:

www.SSRN.com

www.RePEc.org

www.CESifo-group.org/wp

\section{CESifo}




\title{
CCS - Failing to Pass Decision Gates
}

\begin{abstract}
Socio-economic criteria for climate projects have been used in analysing the value of the climate benefit of a reduction in CO2. These reports are optimistic, yet CCS demonstration plants are not implemented as expected. Little attention has been devoted to profitability assessments based on commercial considerations. Economic valuation of climate projects, seen from the perspective of the commercial companies which are to implement the projects, is the subject of this article. We examine key economic parameters of 27 oil and gas projects and compare it to a CCS project. We find that the CCS project ranks the lowest and is unlikely to be implemented by a private company. Our findings may explain why it is hard for oil companies to justify climate projects in their portfolios.
\end{abstract}

JEL-Code: Q380, Q530, Q540.

Keywords: climate projects, decision analysis, $\mathrm{CO} 2$.

\author{
Magne Emhjellen \\ Petoro AS \\ P O Box 300 Sentrum \\ Norway-4002 Stavanger \\ magne.emhjellen@petoro.no
}

\author{
Petter Osmundsen \\ Department of Industrial Economics and \\ Risk Management \\ University of Stavanger \\ Norway - 4036 Stavanger \\ petter.osmundsen@uis.no
}

home page: WWW.uis.no/Osmundsen

We would like to thank a number of specialists in business, the civil service and the academic community for useful comments and suggestions. Financial support from the Norwegian Research Council is appreciated. 


\section{Introduction}

There has been considerable optimism with respect to the development of plants for carbon capture and storage (CCS). The results, however, are disappointing. The EU risks ending up with not a single CCS demonstration plant. ${ }^{2}$ According to World Energy Outlook 2012 by OECD/IEA there has been stagnation in the development of new CCS-projects, and the number of projects executed is just a small fraction of the number presumed in previous CCS studies. This paper examines the reasons behind this planning gap.

Many of the optimistic CCS-reports are based on socio-economic calculations. Little attention has been devoted to profitability assessments based on commercial considerations. Climate projects will normally be executed by private players, for whom decision criteria developed from a commercial perspective are important. Discrepancies between these two types of economic calculations, socio-economic versus commercial, are vital to the planning gap.

Technical obstacles and a low CCS quota price after the financial crisis are obvious explanations. In addition, as shown in Emhjellen and Osmundsen (2013), the private companies that are to implement CCS projects have considerably higher rates of return requirement than what is presumed in previous CCS reports. In addition to return requirements there are other factors that may make investments in CCS for a private company unlikely. These are factors like capital or organizational constraints, political risk or key performance indicators like ROCE (Return on Capital Employed). We examine and discuss these issues related to CCS and compare it to the last 27 oil and gas developments on the NCS (Norwegian Continental Shelf).

The question we ask is whether an oil company would be interested in investing in a CCS project. A CCS plant could be seen as part of the value chain of an oil company in the sense that gas power plants use gas as an input and petroleum production may use gas generated power as an input. Moreover, the systematic risk of petroleum production and a CCS plant is similar - oil and $\mathrm{CO}_{2}$-quotas have about the same beta-value. ${ }^{3}$ Petroleum projects and a CCS plant also have similar cash flow structure, with high front end loading of costs. The CCS

2

http://www.europeanenergyreview.eu/site/pagina.php?email=petter.osmundsen@uis.no\&id_mailing=330\&id=39 $\underline{67}$

${ }^{3}$ Emhjellen and Osmundsen (2013), 
project we analyse would be in connection to a gas power plant partially owned by the Norwegian oil company Statoil.

\section{CCS project at Kårstø, Norway}

The project is described in NVE (2006) and Osmundsen and Emhjellen (2010). Flue gases from Naturkraft's gas-fired power station provide the $\mathrm{CO}_{2}$ source for the capture process. The station will have a net capacity of about 420 megawatts and release up to two million normal cubic metres of flue gases per hour when operating at full load. The station is a "combined cycle" facility which uses the waste heat from the primary gas turbine to generate additional electricity from a steam turbine. It is equipped with an efficient treatment plant for nitrogen oxides which removes virtually all $\mathrm{NO}_{\mathrm{x}}$ (residual emissions are expected to be five parts per million of ammonia $\left(\mathrm{NH}_{3}\right)$ and roughly $2 \mathrm{ppm} \mathrm{NO}_{\mathbf{x}}$ ). Emissions of sulphur oxides, unburnt hydrocarbons and particles will also be very low. The gas turbine burns natural gas with a large excess of air to avoid excessive combustion temperatures and to cool the internal turbine materials. The flue gas volume is therefore large, and the flue itself will have a diameter of about eight metres. The principal fuel gas components will be (vol \%): nitrogen 75\%, oxygen $12 \%$, steam $8 \%$ and $\mathrm{CO}_{2} 4 \%$.

Carbon capture from the power station will occur in a chemical absorption plant ("postcombustion”). This facility will be amine-based. The principal disadvantage of an amine process is the high costs associated with energy consumption in the capture plant. It also involves some emissions of amines and other substances to the air. In full operation, the plant will typically be able to capture about 131 tonnes of $\mathrm{CO}_{2}$ per hour. That represents about 3 150 tonnes per day or roughly 1.05 million tonnes per annum, assuming an uptime of 8000 hours. This means that the power station would release about 0.2 million tonnes of $\mathrm{CO}_{2}$ per annum, rather than 1.25 million without carbon capture over 8000 hours of uptime. The NVE report operates with 8000 hours of uptime for the station - in other words, full capacity utilisation. That is completely unrealistic for this facility, which is meant to swing up and down in line with electricity prices, and must accordingly be adjusted. We have set uptime to $50 \% .{ }^{4}$

\footnotetext{
${ }^{4}$ The projection of Terramar and Asplan Viak (2010) is that the Kårstø plant is most likely to be in operation in Summer, but state that is takes a very favourable relation between power price, gas price and quota price to instigate an operation time that exceeds 4000 hours a year.
} 
The main design principles for an amine-based capture plant will not vary much between different suppliers. This facility is based on flue gases from the power station and utilises an absorption fluid - either an amine or a blend of amines dissolved in water - which absorbs the $\mathrm{CO}_{2}$ from the fumes. Electricity and steam are used as the energy sources for all rotating machinery (compressors, pumps and so forth). Power consumption by the actual capture plant is substantial. Compressing and pumping captured $\mathrm{CO}_{2}$ also requires considerable energy. The use of power for all rotating equipment (source electricity) is a loss of 30MW while the use of steam power will take an additional 36MW resulting in a total loss of 66MW (NVE report, 2006). In other words, power station efficiency will be substantially reduced - about 16 per cent.

In seeking to identify solutions for carbon transport and storage, the NVE has given weight to investigating the options which might be available without making a final concept choice. Optimal storage security is achieved when $\mathrm{CO}_{2}$ is held in abandoned oil or gas fields which have demonstrated their ability to retain natural gas for millions of years.

\section{The oil and gas projects, and price assumptions}

The oil and gas projects are summarized by data from Rystad Energy in table 2 below. 


\section{Valemon}

Gudrun

Ekofisk South

Eldfisk II

Yme

Martin Linge

Edvard Grieg

Skarv

Knarr

Goliat

Gjøa

Vega + Vega sør

Stjerne

Vigdis Northeast

Skuld

Visund South

Njord NW Flank

Visund North

Vilje South

Hyme

Trym

Oselvar

Alta

Marulk

Gaupe

Jette

Brynhild

\begin{tabular}{ccc}
$\begin{array}{c}\text { Expected } \\
\text { Starup }\end{array}$ & $\begin{array}{c}\text { Capex } \\
\text { Mill Euro 2012 }\end{array}$ & Million Boe \\
\hline 2014 & -3360 & 211 \\
2014 & -2372 & 123 \\
2014 & -3405 & 189 \\
2015 & -4737 & 252 \\
2015 & -1764 & 75 \\
2015 & -3205 & 195 \\
2016 & -3026 & 182 \\
2012 & -5895 & 437 \\
2014 & -1441 & 58 \\
2014 & -4643 & 242 \\
2010 & -4181 & 354 \\
2010 & -1289 & 146 \\
2013 & -622 & 45 \\
2013 & -558 & 33 \\
2013 & -1268 & 91 \\
2012 & -651 & 98 \\
2012 & -225 & 19 \\
2013 & -651 & 29 \\
2014 & -138 & 8 \\
2013 & -598 & 26 \\
2011 & -391 & 36 \\
2012 & -640 & 53 \\
2012 & -173 & 11 \\
2012 & -560 & 74 \\
2012 & -297 & 31 \\
2013 & -364 & 13 \\
2013 & -572 & 20 \\
& &
\end{tabular}

Table 1: Latest 27 plans for development and operation in Norway.

The Capex figures are converted to Euro using an exchange rate of 1 Euro=1 Nok.

We use the above data to compare the oil and gas projects with the CCS project. For comparison we assume a capex profile of $30 \%, 40 \%, 30 \%$ in the year before startup and make the same assumption for the CCS project. In addition, for simplification, we assume that the resources in the oil and gas projects are produced evenly over 10 years for resources greater than 50 million barrels of oil equivalents and in 4 years for resources less than 50 million barrels a year. We assume, based on the cost increases related to construction from 2010 to 2012, that the capital cost for the CCS project has increased from 1.13 billion Euro to 1.25 billion Euro 2012. We also expect the operating cost per year to have increased from our previous estimate of 9.4 million nok per year (2010) to 11.25 million Euro per year (2013).

In calculating the net present value of the projects we use the $6,3 \%$ required nominal rate of return estimated for a CCS project in Emhjellen and Osmundsen (2012) and use the unlevered 
petroleum producing beta from Damodaran (data as of January 2013) to estimate the nominal required rate of return for an upstream petroleum project to 9\% (using the other market assumptions as in Emhjellen and Osmundsen 2012).

As for expected price assumption by the oil companies we use an oil equivalent price per barrel of 80 USD 2013. We assume an operating cost per bbl of 20 USD so that the net price per bbl is 60 USD per bbl equal to 45 Euro per barrel (assuming 075 Euro=1 Usd).

As an expected price assumption for the CCS project we use the middle scenario presented in Figure 1: a straight line price increase from a level of 28 euro/tonne in 2016 to 40 euro/tonne in 2020. It is generated by Norway's Climate Cure programme ${ }^{5}$. We assume a real $5 \%$ increase per year after 2020 (many might consider this optimistic given the current outlook).

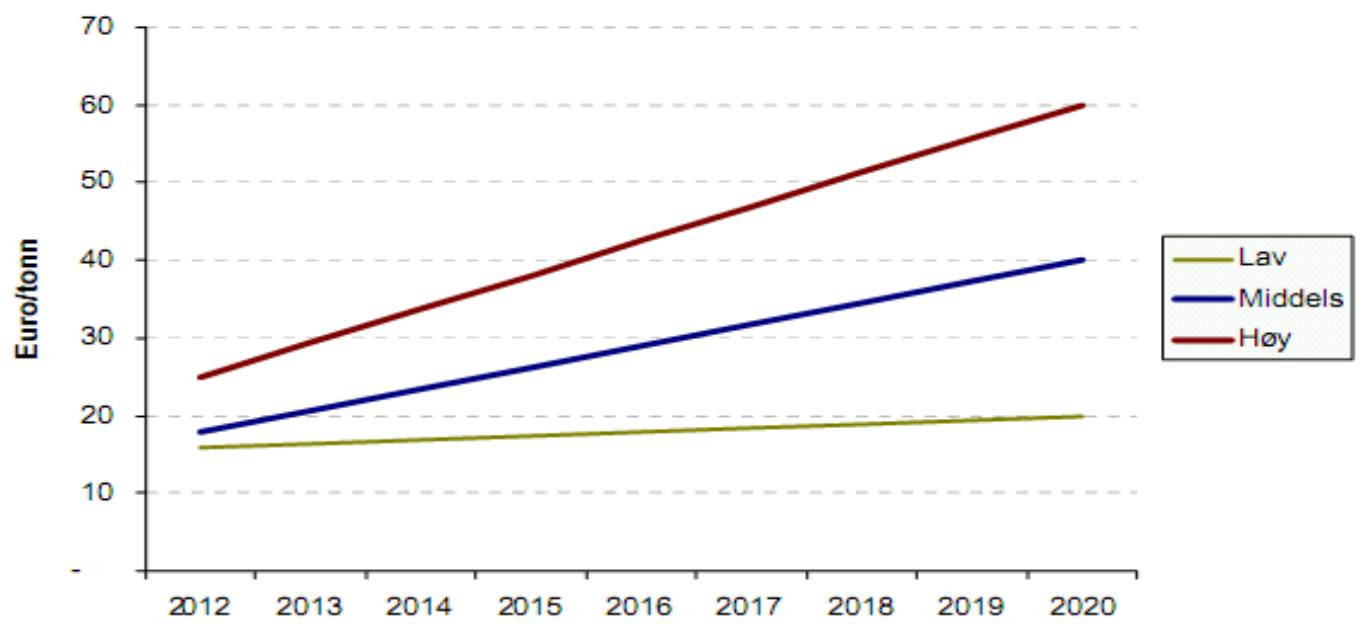

Figure 1: Estimated quota price per tonne (euro)

\section{Rate of return and NPV comparison}

The net present values and the internal rate of returns are presented below. The results clearly show a negative net present value of the CCS project. We introduce a subsidy element to see what level of grants a government would have to offer to make the net present value equal to zero (assuming no taxes on later revenues). In our example case the tax payers would have to

\footnotetext{
${ }^{5}$ Climate Cure 2020 is assessing possible ways to reduce Norway's greenhouse gas emissions by 15-17 million tonnes by 2020 as the basis for a government evaluation of national climate policy. The work has been undertaken by a set of government agencies.
} 
pay $68 \%$ of the 1.25 billion Euro in investments. The results show that the oil projects are profitable with after tax net present values ranging from 152 million to more than 10 billion while the CCS has negative net present value. The internal rate of return ranges from $10,2 \%$ to $58,5 \%$ for the oil projects while the CCS has a negative $2 \%$ internal rate of return. Table 2 shows the key results.

\begin{tabular}{|c|c|c|c|}
\hline & & & \\
\hline Valemon & 2505 & 551 & $19.5 \%$ \\
\hline Gudrun & 1099 & 242 & $15.3 \%$ \\
\hline Ekofisk South & 1898 & 418 & $16.7 \%$ \\
\hline Eldfisk II & 2359 & 519 & $15.8 \%$ \\
\hline Yme & 392 & 86 & $11.2 \%$ \\
\hline Martin Linge & 2228 & 490 & $18.8 \%$ \\
\hline Edvard Grieg & 2049 & 451 & $18.5 \%$ \\
\hline Skarv & 6118 & 1346 & $23.4 \%$ \\
\hline Knarr & 236 & 52 & $10.2 \%$ \\
\hline Goliat & 2183 & 480 & $15.4 \%$ \\
\hline Gjøa & 5477 & 1205 & $26.8 \%$ \\
\hline Vega + Vega sør & 2639 & 581 & $34.9 \%$ \\
\hline Stjerne & 856 & 188 & $41.7 \%$ \\
\hline Vigdis Northeast & 538 & 118 & $33.2 \%$ \\
\hline Skuld & 1238 & 272 & $22.6 \%$ \\
\hline Visund South & 1959 & 431 & $44.0 \%$ \\
\hline Njord NW Flank & 394 & 87 & $48.5 \%$ \\
\hline Visund North & 333 & 73 & $22.4 \%$ \\
\hline Vilje South & 129 & 28 & $32.6 \%$ \\
\hline Hyme & 286 & 63 & $21.6 \%$ \\
\hline Trym & 778 & 171 & $52.6 \%$ \\
\hline Oselvar & 808 & 178 & $26.2 \%$ \\
\hline Alta & 191 & 42 & $36.3 \%$ \\
\hline Marulk & 1420 & 312 & $39.7 \%$ \\
\hline Gaupe & 705 & 155 & $58.5 \%$ \\
\hline Jette & 86 & 19 & $14.8 \%$ \\
\hline Brynhild & 121 & 27 & $14.0 \%$ \\
\hline CCS & -744 & -164 & $-2.0 \%$ \\
\hline CCS subsidies & -744 & 0 & $6.3 \%$ \\
\hline
\end{tabular}

Table 2: Net present values and internal rate of returns

\section{Capital constraints and other scarce inputs}

Basic investment theory, abstracting from capital constraints, recommends that all projects with a positive NPV should be implemented. However, the basic theory abstracts from the fact that company often prefer a fairly stable investment profile, to avoid organizational costs of rapid growth and subsequent cut backs. To allocate scarce capital the oil companies applies a ranking criterion called NPV index, which is defined by NPV of the project divided by NPV 
of the capital investment. ${ }^{6}$ NPV of the project is always in after-tax terms, whereas NPV of the capital investment can be before or after tax. If capital is perceived to be the scarce input factor, the after-tax value is relevant as some of the capital exposure is reduced by tax depreciation. If other inputs are the scarce factor, e.g., specialized type of personnel, the before-tax value of capital investment is applied, as the before-tax investment is used as a proxy for the need for specialized personnel.

CCS is marginal in economic terms and at the same time very capital intensive. This will presumably lead to a low net present value index. As CCS projects may be more capital intensive than petroleum projects, these additional issues may reinforce our explanation as to why it is hard for oil companies to justify climate projects in their portfolios. A CCS project might be harder to implement in times of capital constraints. CCS projects may struggle in comparison with petroleum projects on such rankings, both due to higher capital commitments and lower net present value.

In Table 3 below the net present value indexes and the payback years for the real cash flow are calculated. We see that the CCS project does not have positive values for NPV indexes while the oil projects range from 0,04 (Knarr) to 0,69 (Visund South) when NPV after tax is divided by before tax cost. For the NPV index after tax divided by after tax cost the oil projects have values ranging from 0,16 (Knarr) to 3,01 (Visund South). With the same tax system this ranking will of course be the same, but when companies have international portfolios the ranking will differ.

We see that the CCS-project has a much longer pay-back time than the petroleum projects, even when we make the assumption that the government will make a grant sufficient to make the NPV positive. Pay-back time is used by oil companies in circumstances of high political risk. In those cases they prefer to get their money back fast. Petroleum projects in Norway are perceived to have a very low political risk, so this decision criterion is not relevant here. However, it will be relevant to the CCS project as is heavily relies on government grants. The investors might fear that the grant may go away with a new government or that the plant may have to pay taxes if successful. The major revenue from CCS is CCS quotas, with a highly volatile value. ${ }^{7}$ They differ from other volatile prices as they are highly influenced by political

\footnotetext{
${ }^{6}$ Emhjellen et al. (2006).

${ }^{7}$ Emhjellen and Osmundsen (2013).
} 
decisions. Thus, the overall political risk is very high. Companies often dislike political risk as it is hard to estimate. A pay-back time of 14 is in this context too high.

\begin{tabular}{|c|c|c|c|}
\hline & $\begin{array}{c}\text { NPV after } \\
\text { tax/Sum } \\
\text { Capex } \\
\end{array}$ & $\begin{array}{l}\text { NPV after } \\
\text { tax/Sum } \\
\text { Capex } \\
\text { after tax }\end{array}$ & $\begin{array}{c}\text { Payback } \\
\text { year }\end{array}$ \\
\hline Valemon & 0.18 & 0.75 & 4 \\
\hline Gudrun & 0.11 & 0.46 & 5 \\
\hline Ekofisk South & 0.13 & 0.56 & 5 \\
\hline Eldfisk II & 0.12 & 0.50 & 5 \\
\hline Yme & 0.06 & 0.22 & 6 \\
\hline Martin Linge & 0.16 & 0.70 & 4 \\
\hline Edvard Grieg & 0.16 & 0.68 & 4 \\
\hline Skarv & 0.24 & 1.04 & 4 \\
\hline Knarr & 0.04 & 0.16 & 6 \\
\hline Goliat & 0.11 & 0.47 & 5 \\
\hline Gjøa & 0.30 & 1.31 & 3 \\
\hline Vega + Vega sør & 0.47 & 2.05 & 2 \\
\hline Stjerne & 0.31 & 1.38 & 2 \\
\hline Vigdis Northeast & 0.22 & 0.96 & 2 \\
\hline Skuld & 0.23 & 0.98 & 4 \\
\hline Visund South & 0.69 & 3.01 & 3 \\
\hline Njord NW Flank & 0.40 & 1.75 & 3 \\
\hline Visund North & 0.12 & 0.51 & 2 \\
\hline Vilje South & 0.21 & 0.94 & 2 \\
\hline Hyme & 0.11 & 0.48 & 3 \\
\hline Trym & 0.45 & 1.99 & 1 \\
\hline Oselvar & 0.29 & 1.26 & 3 \\
\hline Alta & 0.25 & 1.11 & 2 \\
\hline Marulk & 0.59 & 2.54 & 2 \\
\hline Gaupe & 0.54 & 2.37 & 1 \\
\hline Jette & 0.06 & 0.24 & 3 \\
\hline Brynhild & 0.05 & 0.21 & 3 \\
\hline CCS & -0.13 & -0.02 & Never \\
\hline CCS subsidies & 0.00 & 0.00 & 14 \\
\hline
\end{tabular}

Table 3: NPV Indexes and payback years

\section{Key performance indicators-ROACE}

In the case of symmetric information between investors and oil companies, net present values of projects would be decisive of project selection. However, investors are not able to observe the companies' project calculations. Instead they observe aggregate financial statements and 
use financial metrics calculated on aggregate financial numbers to infer the underlying profitability. Among the inputs to investors valuation of companies is a comparison of key financial metrics of a given company to that of a peer group. Also, the observed metrics are compared to the companies' stated targets for the metrics, and investors analyse trends in key metrics. In this section we discuss how CCS is likely to score on Return on capital employed (ROCE), and Return on average capital employed (ROACE), two key financial metrics. ${ }^{8}$

To evaluate the performance on ROCE and ROACE of adding an additional project for an oil company that has a portfolio of the 27 projects, we estimate the effect of adding the petroleum project Edvard Grieg and the CCS project to the portfolio from the year of investment through year 7 of production. As shown in Table 4 the Edvard Grieg project will increase both the ROCE and ROACE by about $0.3-0.4 \%$ in the producing years, whereas the CCS will never contribute positively due to low income relative to depreciations. Clearly, the CCS is not attractive in this respect either.

\begin{tabular}{|c|c|c|c|c|c|c|c|c|c|c|c|}
\hline & & 2013 & $\underline{2014}$ & 2015 & $\underline{2016}$ & 2017 & $\underline{2018}$ & 2019 & 2020 & 2021 & 2022 \\
\hline \multirow[t]{2}{*}{ Base Portfolio } & ROCE & $\overline{7.26} \%$ & $7.73 \%$ & $7.08 \%$ & $7.33 \%$ & $\overline{6.53} \%$ & $\overline{6.63} \%$ & $6.78 \%$ & $5.67 \%$ & $5.79 \%$ & $4.18 \%$ \\
\hline & ROACE & $8.72 \%$ & $8.89 \%$ & $7.90 \%$ & $7.24 \%$ & $6.46 \%$ & $6.55 \%$ & $6.70 \%$ & $5.62 \%$ & $5.73 \%$ & $4.15 \%$ \\
\hline \multirow[t]{2}{*}{ with Edvard Grieg } & ROCE & $7.21 \%$ & $7.63 \%$ & $6.98 \%$ & $7.64 \%$ & $6.87 \%$ & $6.98 \%$ & $7.15 \%$ & $6.08 \%$ & $6.21 \%$ & $4.63 \%$ \\
\hline & ROACE & $8.68 \%$ & $8.80 \%$ & $7.79 \%$ & $7.54 \%$ & $6.79 \%$ & $6.90 \%$ & $7.07 \%$ & $6.01 \%$ & $6.14 \%$ & $4.58 \%$ \\
\hline \multirow[t]{2}{*}{ with CCS } & ROCE & $7.24 \%$ & $7.69 \%$ & $7.04 \%$ & $7.30 \%$ & $6.50 \%$ & $6.60 \%$ & $6.76 \%$ & $5.66 \%$ & $5.78 \%$ & $4.18 \%$ \\
\hline & ROACE & $8.70 \%$ & $8.85 \%$ & $7.86 \%$ & $7.20 \%$ & $6.43 \%$ & $6.53 \%$ & $6.68 \%$ & $5.60 \%$ & $5.72 \%$ & $4.14 \%$ \\
\hline \multirow[t]{2}{*}{ delta with EG } & ROCE & $-0.06 \%$ & $-0.10 \%$ & $-0.10 \%$ & $0.31 \%$ & $0.34 \%$ & $0.36 \%$ & $0.37 \%$ & $0.40 \%$ & $0.42 \%$ & $0.45 \%$ \\
\hline & ROACE & $-0.04 \%$ & $-0.10 \%$ & $-0.11 \%$ & $0.30 \%$ & $0.33 \%$ & $0.35 \%$ & $0.36 \%$ & $0.39 \%$ & $0.41 \%$ & $0.44 \%$ \\
\hline \multirow[t]{2}{*}{ delta with CCS } & ROCE & $-0.02 \%$ & $-0.04 \%$ & $-0.04 \%$ & $-0.04 \%$ & $-0.03 \%$ & $-0.03 \%$ & $-0.02 \%$ & $-0.01 \%$ & $-0.01 \%$ & $0.00 \%$ \\
\hline & ROACE & $-0.02 \%$ & $-0.04 \%$ & $-0.05 \%$ & $-0.04 \%$ & $-0.03 \%$ & $-0.03 \%$ & $-0.02 \%$ & $-0.01 \%$ & $-0.01 \%$ & $0.00 \%$ \\
\hline
\end{tabular}

Table 4: ROCE and ROACE effects

\section{Discussion}

In an attempt to explain the unwillingness of private companies to take on CCS projects, we analyze empirically whether an oil company would be interested in investing in a CCS project. A Norwegian CCS project is compared to a number of petroleum projects at the Norwegian continental shelf. We find many explanations why the CCS project is ranked lowest. From all the projects we analyze, the CCS project ranks lowest on project profitability, measured by net present value and internal rate of return. When capital or other input factors are scarce, oil companies apply net present value indexes to rank projects. The CCS project also struggle in comparison with petroleum projects on such rankings, both due

\footnotetext{
${ }^{8}$ See Osmundsen et al. (2006) and Misund et al. (2008).
} 
to higher capital commitments and lower net present value. In projects with perceived high political risk, oil companies prefer a short pay-back time for projects. We find that the CCSproject has a much longer pay-back time than the petroleum projects. Compared to oil and gas projects, the CCS project has low income relative to depreciations, hence it would also have an unfavourable impact on the company’s Return on Capital Employed, ROCE. This is a financial metric used by financial analysts in valuation of companies.

\section{References}

Emhjellen, M., Hausken, K., and P. Osmundsen (2006), ”The Choice of Strategic Core Impact of Financial Volume", International Journal of Global Energy Issues, Vol. 26, No. 1/2, 136-157.

Emhjellen, M and P. Osmundsen (2013), "Rate of Return Requirement for Climate Versus Petroleum Projects”, forthcoming in SPE Economics and Management.

Misund, B, F. Asche, and P. Osmundsen (2008), "Industry Upheaval and Valuation: Empirical Evidence from the International Oil and Gas Industry”, The International Journal of Accounting 43, 4, 398-424.

NVE report, 2006:13. $\mathrm{CO}_{2}$-håndtering på Kårstø. Fangst, transport, lagring ( $\mathrm{CO}_{2}$-handling at Kårstø. Capturing, transportation, storage).

OECD/IEA (2012), World Energy Outlook.

Osmundsen, P., Asche, F., B. Misund, and K. Mohn (2006), "Valuation of International Oil Companies ”, Energy Journal, 27, 3, 49-64.

Osmundsen, P. and M. Emhjellen (2010), ”CCS from a gas-fired power station? A commercial analysis”, Energy Policy 38 (2010) 7818-7826.

Terramar and Asplan Viak (2010), $\mathrm{CO}_{2}$-fangst, -transport og -lagring fra gasskraftverket på Kårstø ( $\mathrm{CO}_{2}$-capture, -transportation and -storage from the gas power plant at Kårstø), report commissioned by the Norwegian Ministry of Finance to evaluate the Kårstø CCS project. 